\title{
Parental attitudes towards mandatory vaccination; a systematic review
}

Louise E. Smith, ${ }^{1,2}$ Ava Hodson, ${ }^{2,3}$ G. James Rubin ${ }^{1,2}$

1 King's College London, Department of Psychological Medicine

2 NIHR Health Protection Research Unit in Emergency Preparedness and Response

3 King's College London, Department of War Studies

Corresponding author: Louise E Smith. Department of Psychological Medicine, King's

College London, Weston Education Centre, Cutcombe Road, London, SE5 9RJ. Email:

louise.e.smith@kcl.ac.uk

Short running title: SR of parental views of mandatory vax

Conflict of interest statement: This study was funded by the National Institute for Health

Research Health Protection Research Unit (NIHR HPRU) in Emergency Preparedness and

Response, a partnership between Public Health England, King's College London and the

University of East Anglia. The views expressed are those of the authors and not necessarily

those of the NIHR, Public Health England or the Department of Health and Social Care. 


\begin{abstract}
While mandatory vaccination schemes can increase vaccine uptake rates, they can also cause backlash among some parents. We conducted a systematic review investigating parental beliefs about vaccine mandates and factors associated with support for mandatory vaccination schemes. We searched Embase, Ovid MEDLINE, Global Health, APA PsycINFO and Web of Science from inception to $17^{\text {th }}$ September 2020. Seventeen studies (five qualitative, twelve quantitative) were eligible for inclusion. We synthesised results of qualitative and quantitative studies separately. Studies were heterogeneous with regard to schemes investigated and factors investigated. Quantitative studies found little evidence for any factors being consistently associated with support for mandatory vaccination. Qualitative studies found that parents perceived mandatory vaccination schemes as an infringement of their rights and that they preferred universal, compared to targeted, schemes. To optimise engagement with existing child mandatory vaccination legislation, schemes should be designed with parental beliefs in mind.
\end{abstract}

Keywords: exemptions, child vaccination; vaccine refusal; vaccine hesitancy; uptake; policy 


\section{Introduction}

While vaccines have substantially reduced morbidity and mortality for various diseases,[1] some parents choose not to vaccinate their child. In the UK, uptake of routine childhood vaccines has been decreasing for the last five years.[2] Vaccine uptake has also been decreasing in the United States (US) and elsewhere globally.[3] One way of increasing uptake is make childhood vaccination mandatory. As of December 2018, 105 countries had a nationwide vaccine mandate in operation.[4] Other countries such as the US and Canada, do not have a nationwide mandate, but have mandates that vary on a regional basis.[5-7] Mandatory vaccine schemes tend to restrict access to child-care or schooling for children who are not vaccinated, or withhold state payments or benefits if children are not vaccinated.[4] In some circumstances, parents can apply for exemptions to vaccine mandates based on religious or personal beliefs, but the flexibility within policies varies widely.[4] Another way of promoting vaccination could be to offer financial incentives.

Making vaccinations mandatory tends to increase uptake.[8] However, there is substantial debate over the ethics of making vaccination mandatory.[9] While mandatory vaccination may force people to overcome barriers to vaccination, such as having to make a primary care appointment, it may entrench negative perceptions of vaccination.[10] In some countries, the implementation of mandatory vaccination programs has led to increased anti-vaccination sentiments and negative vaccine messages in the media.[11, 12] In Germany, these negative sentiments impacted vaccination intentions for other recommended, but non-mandatory, vaccinations.[12] In the US, systematic differences in uptake of child vaccines still exists, with evidence of geographical clustering of vaccine exemptions.[13]

There is no standard approach to mandatory vaccination programmes.[14] Approaches vary country to country by: which vaccines are mandatory; which age groups are included; and 
how flexible the mandate is (e.g. penalties, enforcement, ability to opt out, compensation for serious adverse events). Refusal is often allowed based on religious, moral, philosophical or personal reasons. To minimise backlash when implementing a new childhood vaccine mandate, and to optimise engagement with existing childhood mandatory vaccination legislation, schemes should be designed with parental beliefs in mind. One recent systematic review investigated parental beliefs towards mandatory vaccination, h but with major limitations.[15, 16] Another systematic review focused on acceptability, economic costs and incentives of specific schemes, but is now outdated having been conducted in 2013.[17]

There are no recent, high quality reviews investigating parental beliefs and attitudes towards vaccine mandates for routine childhood vaccinations.

The aim of this study was to investigate parents' beliefs about vaccine mandates and factors associated with support for mandatory vaccination schemes.

\section{Method}

We conducted a systematic review in accordance with PRISMA criteria [18] to investigate parents' beliefs and attitudes towards vaccine mandates and mandatory vaccination. We searched Embase, Ovid MEDLINE, Global Health and APA PsycINFO through OvidSP, and Web of Science. Our final search term combined terms related to: mandatory, compulsory, exemptions, or school entry requirements; vaccination or immunisation; beliefs, or attitudes; and children (see supplementary materials). Databases were searched from inception to $17^{\text {th }}$ September 2020. References and forward citations of included articles were also searched.

$\underline{\text { Inclusion criteria }}$

The following inclusion criteria were used: 
Participants: Studies were included if they investigated parental beliefs. Studies were excluded if they investigated healthcare workers' beliefs about vaccine mandates, or if they investigated attitudes towards mandatory vaccination in populations other than children.

Predictors/exposures: Studies were included if they investigated factors associated with vaccine mandates or support for mandatory vaccination schemes, or if endorsement of vaccine mandates or mandatory vaccination was described.

Outcome: Beliefs and attitudes about vaccine mandates for routine childhood vaccinations or the concept of mandatory vaccination. Studies were only included if they investigated a WHO recommended routine vaccination in children (BCG, hepatitis B, polio, DTPcontaining vaccine, haemophilus influenzae type b (Hib), pneumococcal (conjugate), rotavirus, measles, rubella).[19] We excluded studies investigating beliefs about mandates for HPV vaccination, as parental concerns may be influenced by complex underlying attitudes towards sex,[20] which are likely qualitatively different to concerns surrounding vaccine mandates for other routine childhood vaccinations. Studies were also excluded if they solely investigated factors associated with uptake of mandatory vaccines.

Study reporting: Studies were included if they were published in English and presented data. There were no exclusions made based on study design.

\section{$\underline{\text { Data extraction }}$}

We extracted information about study design, inclusion criteria, participant characteristics, country of study, and attitudes towards vaccine mandates or mandatory vaccination.

\section{$\underline{\text { Risk of bias }}$}

Risk of bias was measured using the mixed methods appraisal tool (MMAT).[21] This tool allows appraisal of different study methods, including qualitative and quantitative studies. The MMAT evaluates studies on five dimensions which vary based on the methods of the 
study. To enable more detailed description of risk of bias in the study, we scored studies out of two on each of the five dimensions, resulting in a total score out of ten. To aid interpretation of results, studies were rated as poor quality if they scored five or under; moderate quality if they scored six or seven; and good quality if they scored eight or over. LS and AH completed risk of bias ratings separately for all studies. Any discrepancies were solved through discussion and final scores were approved by both authors.

\section{$\underline{\text { Procedure }}$}

LS came up with the search terms, carried out the search, screened papers, extracted data and completed risk of bias assessment. AH screened a random sample of 100 citations to full-text screening stage and completed risk of bias assessment. Guidance was provided by GJR.

Qualitative and quantitative data were synthesised separately. Quantitative data were narratively synthesised, considering risk of bias ratings. As studies were heterogeneous in the mandatory vaccination schemes and associated factors investigated, there was no scope to conduct a meta-analysis. Qualitative data were synthesised using meta-ethnography,[22] synthesising themes reported across studies included. 


\section{Results}

\section{$\underline{\text { Study characteristics }}$}

The search identified 4,994 citations; after removing duplicates, 2,672 citations remained.

After title, abstract and full-text screening, seventeen citations remained. A further three

citations were identified by reference searching and forward citation tracking. Thus, twenty citations, reporting on seventeen studies (twelve quantitative, five qualitative) met inclusion criteria (see Figure 1). 


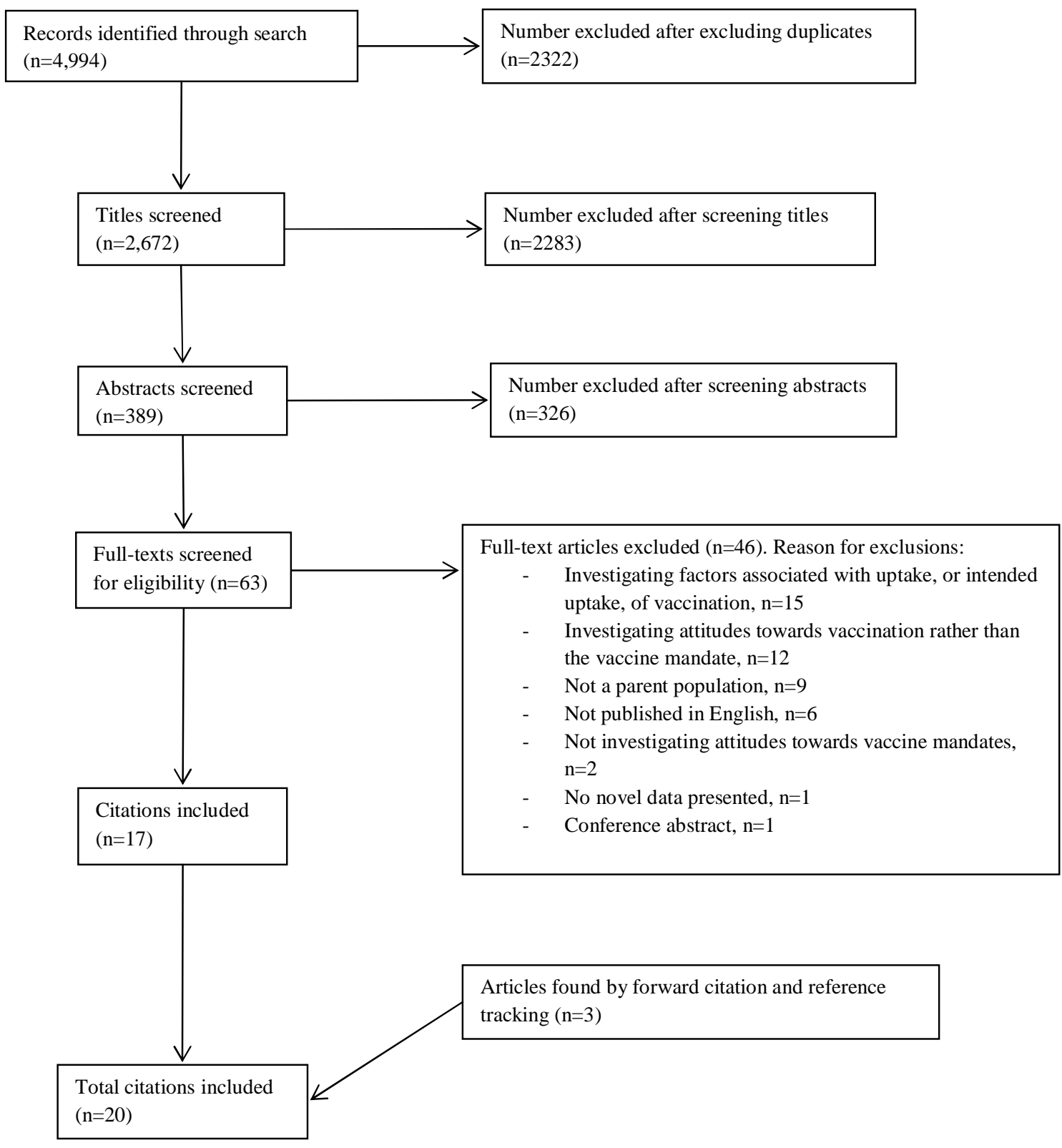

Figure 1. Flowchart depicting the selection of studies for the systematic review, with reasons for exclusion

\section{$\underline{\text { Risk of bias }}$}

Scores for studies ranged between three and ten (see supplementary materials). Qualitative studies scored highly, between nine and ten,[17, 23-27] aside from one short article which scored poorly (five).[28] Two quantitative studies scored highly (eight or nine), [29, 30] and 
were only marked down for not reporting complete outcome data (including 95\% confidence intervals for prevalence estimates) or fully accounting for confounders in the study design or analyses. Five quantitative studies scored six or seven.[17, 23, 31-35] These studies did not report complete outcome data, account for confounders in the study design or analysis, and participants were not representative of the target population or the outcome measure was not robust. Five quantitative studies scored particularly poorly (between three and five).[36-41] These studies were poor across the different dimensions evaluated, but low scores were because participants were not representative of the target population, complete outcome data were not reported, confounders were not accounted for in the study design and analysis, and outcome variables were not robustly measured.

\section{Quantitative studies}

Ten studies used a cross-sectional design, one used a case-control design, and one study was a discrete choice experiment (see supplementary materials). Studies were conducted in the USA ( $n=5)$, Poland $(n=2)$, Israel $(n=2)$, England $(n=1)$, Croatia $(n=1)$, and Australia $(n=1)$. Studies investigated factors associated with support for various mandatory vaccination schemes, including: restricting access to childcare or schooling for children who are not vaccinated; removing religious and personal belief exemptions from childcare or school entry requirements; withholding state payments or benefits if children are not vaccinated; and mandatory vaccination generally.

Support for mandatory vaccination schemes varied. One study found that $47 \%$ of rural Ohio Appalachian (US) parents who had not vaccinated their daughters for HPV believed they had the right to refuse vaccines that were require for their child's school,[35] while another found that $12 \%$ of US parents believed that children should be allowed to go to school even if they were not vaccinated.[30] Support for religious belief exemptions (22\%) was slightly higher 
than support for personal belief exemptions (17\%) in US parents.[34] Another study found that $73 \%$ of Croatian parents of children aged 6 years, attending school health services believed that child vaccination should remain mandatory.[39] In a sample of Australian parents of children under 5 years, $82 \%$ supported the "no jab, no pay" scheme.[29]

Four studies found no evidence for an association between parent gender and support for mandatory vaccination schemes.[29, 30, 35-37] One poor quality study found an association between younger age and lower support for mandatory vaccination, $[36,37]$ while three studies (two good quality, one moderate quality) found no evidence for an association.[29, 30, 35] A further poor quality study found that parents of younger children were less likely to support mandatory vaccination.[41] Lower education was associated with lower support for mandatory vaccination in a moderate quality study,[32] but not a poor quality study.[36, 37] Two further studies (one good quality, one moderate quality) found no evidence for an association between education and support for mandatory vaccination schemes restricting access to child-care or schooling only to vaccinated children.[30, 35] Lower household income was associated with lower support for mandatory vaccination schemes in which childcare or schooling is limited to vaccinated children in a good quality study,[30] while a moderate quality study found no evidence for an association.[35] Lower household income was also associated with lower support for mandatory vaccination in a poor quality study.[36, 37] White ethnicity was associated with support for restrictions in eligibility for childcare or schooling for unvaccinated children.[30] There was no evidence for an association between ethnicity and the "no jab, no pay" scheme.[29] Both studies investigating associations with ethnicity were good quality studies. Larger household size [30] and not being in full-time employment [35] were associated with lower support for a school-entry or childcare entrybased vaccination scheme. Poorer health literacy was associated with lower support for mandatory vaccination in one moderate quality study.[32] There was no evidence for an 
association between the child having previously experienced an adverse effect from vaccination and support for mandatory vaccination in a poor quality study.[36, 37] There was also no evidence that support for mandatory vaccination schemes changed between 2008 and 2016 in a moderate quality study.[33]

Parents of US children who were home-schooled were less supportive of mandatory vaccination,[40] and more supportive of allowing religious belief exemptions and personal belief exemptions for vaccines required for school-entry.[34, 40] In an Australian study, parents who had previously registered a conscientious objection to vaccination were less likely to support the "no jab, no pay" scheme.[29] Parents in a US study who lived in a state which allowed philosophical exemptions were less likely to support mandatory vaccination for childcare or schooling.[30]

Distrust of the government and of healthcare providers was associated with lower support for mandatory vaccination for childcare or schooling,[38] as was Republican and Independent political affiliation (compared to Democrat) in one US study.[35]

One Australian study found that parents who perceived a lower risk of measles for unvaccinated children were less likely to support the "no jab, no pay" scheme; there was no evidence for an association with needing the financial incentives to afford family expenses or having a child that attends childcare.[29]

\section{Qualitative studies}

Two studies, both conducted in the UK, used a focus group design. Three other studies (conducted in Australia, the USA and Hong Kong) used an interview design. Studies investigated parental beliefs about mandatory vaccination schemes which: offer financial incentives for vaccination; restrict access to childcare or schooling for children who are not vaccinated; remove religious and personal belief exemptions from childcare or school entry 
requirements; withhold state payments or benefits if children are not vaccinated; and which restrict access to child-care or schooling and withhold state payments or benefits if children are not vaccinated.

Seven main themes were extracted from studies (see Table 1). First, parents consistently perceived mandating vaccination as an infringement of their personal rights.[17, 23, 25, 26, 28] In a sample of parents who had refused mandatory vaccination, the mandate had strengthened their commitment to make autonomous medical decisions for themselves and their child.[24] Second, parents thought that schemes should not "punish" the child by not allowing them access to schooling or childcare based on the parents' choice not to vaccinate them (parental preferences for mandatory vaccination schemes).[17, 23, 24, 26] However, they perceived restricting access to schooling and childcare as fairer and more equitable than offering financial incentives for vaccination, and preferred universal rather than targeted schemes.[17, 23, 26] Third, parents perceived financial incentives for vaccination as inappropriate and coercive, $[17,23,24,26]$ and thought that parents may use vaccination schemes as a way to gain additional financial incentives or to secure school spaces (perceived inappropriateness of schemes).[28] Fourth, motivators for vaccination were varied. While one study found that parents thought that protecting the child should be the sole motivation for vaccination,[28] other studies found that parents thought mandatory vaccination could be an incentive for vaccination if their child would otherwise be denied schooling,[27] or if financial incentives could be seen as supplementing one's income.[17, 23, 26] Fifth, mandatory vaccination schemes were perceived as having a disproportionate impact on lowincome families, who may be more reliant on state benefits, financial incentives and who might not have the resources to pay for alternate schooling or childcare.[17, 23, 26, 28] Sixth, parents objected to penalising parents who did not want to vaccinate their child due to safety concerns.[28] Seventh, parents agreed that mandatory vaccination would deliver some "peace 
of mind" through the knowledge that there was no risk of unvaccinated children passing on illnesses in school or childcare settings.[17, 23, 26, 27]

Table 1. Themes and sub-themes identified in studies included

\begin{tabular}{|c|c|}
\hline Theme & Sub-themes \\
\hline $\begin{array}{l}\text { Infringement of } \\
\text { parental rights }\end{array}$ & $\begin{array}{ll}\text { - } & \text { Infringement of parental rights and autonomy }[17,23,26] ;[25] \\
\text { - } & \text { Disempowerment of parents by removal of consent }[28] \\
\text { - } & \text { Commitment to autonomy strengthened [24] }\end{array}$ \\
\hline $\begin{array}{l}\text { Parental } \\
\text { preferences for } \\
\text { mandatory } \\
\text { vaccination } \\
\text { schemes }\end{array}$ & $\begin{array}{l}\text { - Mandatory vaccination schemes should not "punish" the child (e.g. by not being } \\
\text { able to go to school) rather than the parent }[17,23,26] ;[24] \\
\text { - } \\
\text { Restricting access to child-care and schooling only to vaccinated children is } \\
\text { perceived as being preferable, fairer and more equitable to offering financial } \\
\text { incentives for vaccination }[17,23,26] \\
\text { - Universal schemes seen as more equitable and fairer than targeted schemes (e.g. } \\
\text { for those with unvaccinated children, lower socio-economic status). [17, 23, 26] } \\
\text { - Disdain towards withholding state benefits and payments if children are not } \\
\text { vaccinated [24] }\end{array}$ \\
\hline $\begin{array}{l}\text { Perceived } \\
\text { inappropriateness } \\
\text { of schemes }\end{array}$ & $\begin{array}{l}\text { - } \begin{array}{l}\text { Financial incentives seen as inappropriate and coercive }[17,23,26] ;[24] \\
\text { - }\end{array} \text { Schemes requiring vaccination for child-care or schooling and withholding state } \\
\text { benefits inappropriately position vaccination as a means to acquire financial } \\
\text { benefits and secure a school space [28] }\end{array}$ \\
\hline $\begin{array}{l}\text { Motivation for } \\
\text { vaccination }\end{array}$ & 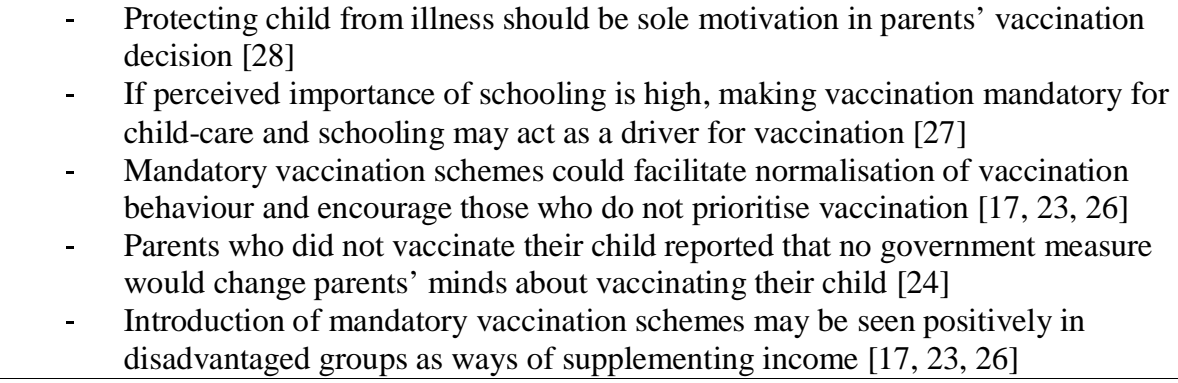 \\
\hline $\begin{array}{l}\text { Disproportionate } \\
\text { impact on low- } \\
\text { income families }\end{array}$ & $\begin{array}{l}\text { - Incentives, penalties and pressure to vaccinate may be more keenly felt by } \\
\text { parents from low-income families who may be more reliant on financial } \\
\text { incentives of vaccination, state benefits, and who would not have the financial } \\
\text { resources to pay for alternative child-care or schooling if their child could not } \\
\text { attend publicly-funded schooling }[28] ;[17,23,26] \\
\text { - May create greater divide between parents who can and cannot afford to } \\
\text { vaccinate their child }[17,23,26]\end{array}$ \\
\hline Safety concerns & 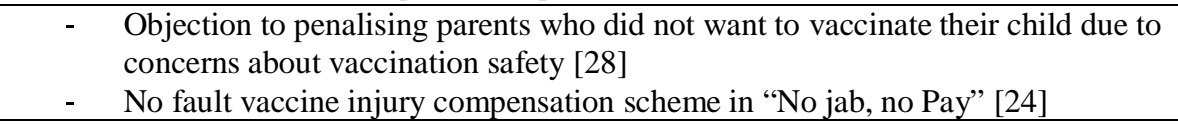 \\
\hline $\begin{array}{l}\text { Risk of } \\
\text { unvaccinated } \\
\text { children in } \\
\text { passing on } \\
\text { illnesses }\end{array}$ & $\begin{array}{l}\text { - Agreement that unimmunised children should be excluded from interacting with } \\
\text { other children in child-care or school settings }[17,23,26] ;[27] \\
\text { - } \quad \text { Give parents "peace of mind" }[17,23,26]\end{array}$ \\
\hline
\end{tabular}

\section{Discussion}

Dropping vaccination rates, such as those seen in the US, UK, and elsewhere, [2] and the recent COVID-19 pandemic have re-ignited discussion about mandatory vaccination.[42] 
While introducing vaccine mandates increases uptake of vaccines, [8] they also have the potential to cause backlash. This may be particularly true for vaccine mandates that are considered to be more stringent.[4] When implementing mandatory childhood vaccination, parents' viewpoints should be considered, to ensure schemes are accepted and to minimise backlash. This review synthesised quantitative and qualitative studies investigating parental beliefs about mandatory vaccination and factors associated with support for vaccine mandates.

Perhaps unsurprisingly, all but one qualitative study found that parents thought schemes were an infringement of their right to choose whether to vaccinate their child. In a sample of parents who had not vaccinated their child, the introduction of a scheme withholding state benefits if children were not vaccinated strengthened their commitment to autonomy in making health decisions.[24] Recent evidence shows that attitudes towards vaccinations are becoming more polarised.[43] Another theme identified in this study was that parents thought they should not be penalised for not wanting to vaccinate their child due to safety concerns. A quantitative study found that support for religious belief exemptions (22\%) was slightly higher than support for personal belief exemptions (17\%) in US parents.[34] Implementing vaccine mandates without considering parents' views on exemption policies could result in considerable backlash among some parents, however the purposive use of non-representative samples in the qualitative studies makes it impossible to identify the prevalence of these views.

Better insight into how many parents this might apply to can be found in quantitative studies. These indicated that support for mandatory vaccination schemes in countries where one had been implemented was reasonably high, ranging between $73 \%$ and $88 \%$ of parents. Support for a mandatory vaccination scheme was much lower in one study (47\%),[35] although this was in a sample of parents who had not vaccinated their daughters for HPV. 
Studies investigated support for different vaccine mandates in which unvaccinated children could not access schooling or childcare, parents did not receive state benefits, or in which parents received financial incentives, and for different aspects of vaccine mandates, such as support for specific exemption schemes. Due to the lack of a standard approach to mandatory vaccination,[14] it is difficult to quantify support for mandatory schemes generally. A more useful approach may be to identify parental preferences for different vaccination schemes. One study included in the review did this, finding that parents preferred universal mandatory vaccination schemes compared to those which targeted parents who had not fully vaccinated their child.[17, 23, 31] Qualitative results also indicated that universal schemes were perceived as fairer and more equitable than targeted schemes, $[17,23,26]$ and that schemes offering financial incentives for vaccination are perceived by some as inappropriate and coercive. $[17,23,24,26]$ Where financial incentives were offered, cash incentives were preferred by parents of children "at risk" for incomplete vaccination (parents of children aged under 5 years currently living in a deprived area; who were aged 20 years or under; single parents or guardians; who have more than three children; and who had a child aged under 5 years with a physical or mental health condition) compared to no incentive, with no preference for voucher incentives compared to no incentives.[17, 23, 31] There was no evidence for this preference in parents of children "not at risk" (parents of children aged under 5 years who did not fit into the previously listed categories).

Despite ethical concerns about mandating vaccinations, [9] another theme extracted from qualitative studies was the view among some parents that unvaccinated children should be excluded from interacting with other children at school or in childcare settings to reduce the risk of passing on illnesses. This would give parents "peace of mind" about the safety of their child. 
Due to heterogeneity of the quantitative studies, there was little evidence for associations between parental support for mandatory vaccination schemes and socio-demographic characteristics and beliefs. There was some evidence that lower household income was associated with lower support for mandatory vaccination schemes. This may reflect lower patterns of vaccine uptake in children of parents with lower incomes generally.[44] One theme extracted from qualitative studies was that mandatory vaccination schemes may have a disproportionate impact on low-income families, with parents being less financially able to seek alternative childcare or schooling arrangements if their child is not vaccinated, or being more reliant on state benefits or financial incentives only given to those whose children are vaccinated. Qualitative findings suggested that disadvantaged groups might support financial incentives as a way of supplementing income.[17, 23, 26] However, there was no association between support for a scheme withholding state benefits for parents of unvaccinated children and needing the benefits to be able to afford family expenses or having a child that attended childcare.[29] Mandatory vaccination schemes should aim to minimise disproportionate impact on low-income families, so as not to create further inequity.

\section{Limitations of studies included in the review}

While qualitative studies included in the review were generally of high quality, quantitative studies were of lower quality. In particular, quantitative studies often did not ensure their samples were representative of the target population or take potential confounders into account in the study design or analyses. Furthermore, outcome data was often not completely reported, and some studies used outcome measures which were not methodologically robust. Some studies investigating parental beliefs about mandatory vaccinations were conducted in countries where vaccination was not mandatory. While this is an important first step if new mandatory vaccination schemes are to be implemented successfully, intentions and concerns about hypothetical situations may not reflect real-world experiences. 


\section{$\underline{\text { Limitations of the review }}$}

Studies were heterogeneous in terms of mandatory vaccination schemes investigated.

Parental concerns and beliefs about schemes mandating vaccination for schooling or childcare may be qualitatively different from schemes using financial incentives to promote vaccination. Few quantitative studies investigated the same predictive factors. This lack of replication meant that even where multiple studies found an association, evidence for that factor remained weak. We have based our interpretation and conclusions on factors that were supported by evidence from both quantitative and qualitative studies.

MeSH terms were not searched, therefore some studies which were eligible for inclusion could have been missed.

\section{$\underline{\text { Conclusion }}$}

While mandatory vaccination schemes increase vaccine uptake rates, they have the potential to cause backlash in some parents. Results from qualitative studies indicated that mandatory vaccination schemes were perceived by some parents as an infringement of their rights.

Nevertheless, some parents also felt that schemes limiting access to schooling of unvaccinated children gave them "peace of mind." Parents preferred universal vaccination schemes, rather than targeted schemes, and particularly disliked schemes offering financial incentives for vaccination. However, these results should be interpreted with caution, taking into account the purposive use of non-representative samples. Quantitative studies reporting rates of endorsement of these views found that support for mandatory vaccination schemes was reasonably high ( $73 \%$ to $88 \%)$. Due to heterogeneity of quantitative studies, there was little evidence for factors consistently associated with support for mandatory vaccination. Parental beliefs about vaccine mandates and factors associated with support for mandatory vaccination may shed light on how to implement schemes to maximise parental endorsement. 


\section{References}

1. Roush SW, Murphy TV, Vaccine-Preventable Disease Table Working Group.

Historical comparisons of morbidity and mortality for vaccine-preventable diseases in the United States. JAMA. 2007;298(18):2155-63.

2. Screening and Immunisations Team, COVER Team. Childhood Vaccination Coverage Statistics; England, 2018-19. 2019. https://files.digital.nhs.uk/4C/09214C/childvacc-stat-eng-2018-19-report.pdf. Accessed 22 November 2020.

3. The Lancet Child Adolescent H. Vaccine hesitancy: a generation at risk. Lancet Child Adolesc Health. 2019;3(5):281.

4. Gravagna K, Becker A, Valeris-Chacin R, Mohammed I, Tambe S, Awan FA, et al. Global assessment of national mandatory vaccination policies and consequences of noncompliance. Vaccine. 2020;38(49):7865-73.

5. The Lancet. Canada's mandatory vaccination reporting plans. The Lancet. 2019;393(10175):960.

6. Walkinshaw E. Mandatory vaccinations: The Canadian picture. CMAJ. 2011;183(16):E1165-E6.

7. Centers for Disease Control and Prevention. Required Vaccines for Child Care and School. 2020. https://www.cdc.gov/vaccines/parents/records/schools.html. Accessed 3 December 2020.

8. Lee C, Robinson JL. Systematic review of the effect of immunization mandates on uptake of routine childhood immunizations. J Infect. 2016;72(6):659-66.

9. Salmon DA, MacIntyre CR, Omer SB. Making mandatory vaccination truly compulsory: well intentioned but ill conceived. Lancet Infect Dis. 2015;15(8):872-3. 
10. Omer SB, Betsch C, Leask J. Mandate vaccination with care. Nature. 2019;571(7766):469-72.

11. Peijin LS. Tightening measures for compliance with vaccination in Serbia. ESPN Flash Report 2016/46. 2016.

12. Betsch C, Bohm R. Detrimental effects of introducing partial compulsory vaccination: experimental evidence. Eur J Public Health. 2016;26(3):378-81.

13. Wang E, Clymer J, Davis-Hayes C, Buttenheim A. Nonmedical exemptions from school immunization requirements: a systematic review. Am J Public Health. 2014;104(11):e62-e84.

14. MacDonald NE, Harmon S, Dube E, Steenbeek A, Crowcroft N, Opel DJ, et al. Mandatory infant \& childhood immunization: Rationales, issues and knowledge gaps. Vaccine. 2018;36(39):5811-8.

15. Gualano MR, Olivero E, Voglino G, Corezzi M, Rossello P, Vicentini C, et al. Knowledge, attitudes and beliefs towards compulsory vaccination: a systematic review. Human Vaccines and Immunotherapeutics. 2019;15(4):918-31.

16. Calo WA, Brewer NT. HPV vaccine requirements, opt-outs and providers' support: Key studies missing from a recent systematic review. Hum Vaccin Immunother. 2020;16(1):128-30.

17. Adams J, Bateman B, Becker F, Cresswell T, Flynn D, McNaughton R, et al. Effectiveness and acceptability of parental financial incentives and quasi-mandatory schemes for increasing uptake of vaccinations in preschool children: Systematic review, qualitative study and discrete choice experiment. Health Technol Asses. 2015;19(94):vii-xxv,1-176.

18. Moher D, Liberati A, Tetzlaff J, Altman DG, Group P. Preferred reporting items for systematic reviews and meta-analyses: the PRISMA statement. BMJ. 2009;339:b2535. 
19. World Health Organization. Table 1: Summary of WHO Position Papers -

Recommendations for routine immunization. 2020.

https://www.who.int/immunization/policy/Immunization_routine_table1.pdf?ua=1. Accessed

15 September 2020.

20. Larson HJ. A global girl gang. Lancet. 2018 Feb 10;391(10120):527-8.

21. Hong QN, Pluye P, Fabregues S, Bartlett G, Boardman F, Cargo M, et al. Improving the content validity of the mixed methods appraisal tool: a modified e-Delphi study. J Clin Epidemiol. 2019;111:49-59 e1.

22. Britten N, Campbell R, Pope C, Donovan J, Morgan M, Pill R. Using meta ethnography to synthesise qualitative research: a worked example. J Health Serv Res Policy. 2002;7(4):209-15.

23. Adams J, McNaughton RJ, Wigham S, Flynn D, Ternent L, Shucksmith J. Acceptability of parental financial incentives and quasi-mandatory interventions for preschool vaccinations: Triangulation of findings from three linked studies. PLoS ONE. 2016;11(6):e0156843.

24. Helps C, Leask J, Barclay L. "It just forces hardship": impacts of government financial penalties on non-vaccinating parents. Journal of Public Health Policy. 2018;39(2):156-69.

25. McDonald P, Limaye RJ, Omer SB, Buttenheim AM, Mohanty S, Klein NP, et al. Exploring California's new law eliminating personal belief exemptions to childhood vaccines and vaccine decision-making among homeschooling mothers in California. Vaccine. 2019;37(5):742-50.

26. McNaughton RJ, Adams J, Shucksmith J. Acceptability of financial incentives or quasi-mandatory schemes to increase uptake of immunisations in preschool children in the 
United Kingdom: Qualitative study with parents and service delivery staff. Vaccine. 2016;34(19):2259-66.

27. Tarrant M, Thomson N. Secrets to success: A qualitative study of perceptions of childhood immunisations in a highly immunised population. Journal of Paediatrics and Child Health. 2008;44(10):541-7.

28. Gardner B, McAteer J, Davies A, Michie S. Views towards compulsory MMR vaccination in the UK. Arch Dis Child. 2010;95(8):658-9.

29. Trent MJ, Zhang EJ, Chughtai AA, MacIntyre CR. Parental opinions towards the "No Jab, No Pay" policy in Australia. Vaccine. 2019;37(36):5250-6.

30. Kennedy AM, Brown CJ, Gust DA. Vaccine beliefs of parents who oppose compulsory vaccination. Public Health Reports. 2005;120(3):252-8.

31. Flynn D, Ternent L, Becker F, Oluboyede Y, Adams J. Parental Preferences for the Organization of Preschool Vaccination Programs Including Financial Incentives: A Discrete Choice Experiment. MDM Policy Pract. 2017;2(1):2381468317708319.

32. Aharon AA, Nehama H, Rishpon S, Baron-Epel O. Parents with high levels of communicative and critical health literacy are less likely to vaccinate their children. Patient Education and Counseling. 2017;100(4):768-75.

33. Grossman Z, Hadjipanayis A, Degani A, Somekh E. Tracking Changes in Vaccine Attitudes and Decisions: Results from 2008 and 2016 Parental Surveys. Pediatric Infectious Disease Journal. 2019;38(4):E75-E6.

34. Kennedy AM, Gust DA. Parental vaccine beliefs and child's school type. Journal of School Health. 2005;75(7):276-80. 
35. Krok-Schoen JL, Bernardo BM, Weier RC, Peng J, Katz ML, Reiter PL, et al. Belief About Mandatory School Vaccinations and Vaccination Refusal Among Ohio Appalachian Parents: Do Demographic and Religious Factors, General Health, and Political Affiliation Play a Role? The Journal of rural health : official journal of the American Rural Health Association and the National Rural Health Care Association. 2018;34(3):283-92.

36. Krasnicka J, Krajewska-Kulak E, Klimaszewska K, Cybulski M, Guzowski A, Kowalewska B, et al. Mandatory and recommended vaccinations in Poland in the views of parents. Human Vaccines and Immunotherapeutics. 2018;14(12):2884-93.

37. Krasnicka J, Krajewska-Kulak E, Klimaszewska K, Cybulski M, Guzowski A, Lewko J, et al. The impact of parents' health behaviours on their preferences regarding vaccinations in Bialystok, Poland. BMC Pediatr. 2020;20(1):354.

38. Lee C, Whetten K, Omer S, Pan W, Salmon D. Hurdles to herd immunity: Distrust of government and vaccine refusal in the US, 2002-2003. Vaccine. 2016;34(34):3972-8.

39. Makaric ZL, Kolaric B, Tomljenovic M, Posavec M. Attitudes and beliefs related to childhood vaccinations among parents of 6 years old children in Zagreb, Croatia. Vaccine. 2018;36(49):7530-5.

40. Troupe D, Carrol M, McWilliams E, Swift P, Li Y. Homeschoolers' vaccination perception and rate: a comparison with a public/private school population. Californian Journal of Health Promotion. 2017;15(2):46-58.

41. Kalucka SK, Lopata E. Age-conditioned differences in parents' attitudes towards compulsory vaccination. Family Medicine and Primary Care Review. 2016;18(4):425-8.

42. Giubilini A, Jain V. Should COVID-19 vaccines be mandatory? Two experts discuss. 2020. https://theconversation.com/should-covid-19-vaccines-be-mandatory-two-expertsdiscuss-150322. Accessed 3 December 2020. 
43. Lee CHJ, Sibley CG. Attitudes toward vaccinations are becoming more polarized in New Zealand: Findings from a longitudinal survey. EClinicalMedicine. 2020;23:100387.

44. Tabacchi G, Costantino C, Napoli G, Marchese V, Cracchiolo M, Casuccio A, et al. Determinants of European parents' decision on the vaccination of their children against measles, mumps and rubella: A systematic review and meta-analysis. Hum Vacc Immunother. 2016;12(7):1909-23. 


\section{Supplementary materials. Full details of search.}

\begin{tabular}{|l|l|}
\hline 1. & Mandat* \\
\hline 2. & Compulsory \\
\hline 3. & Opt out \\
\hline 4. & Obligatory \\
\hline 5. & Legislation \\
\hline 6. & Policy \\
\hline 7. & Law \\
\hline 8. & School entry \\
\hline 9. & Day care entry \\
\hline 10. & Child care entry \\
\hline 11. & Exempt* \\
\hline 12. & 1 or 2 or 3 or 4 or 5 or 6 or 7 or 8 or 9 or 10 or 11 \\
\hline 13. & Vaccin* \\
\hline 14. & Immuni ${ }^{*}$ \\
\hline 15. & Innoculat* \\
\hline 16. & Shot \\
\hline 17. & Jab \\
\hline 18. & 13 or 14 or 15 or 16 or 17 \\
\hline 19. & Perce* \\
\hline 20. & Belie* \\
\hline 21. & Attitud* \\
\hline 22. & Acceptanc* \\
\hline 23. & Hesitanc* \\
\hline 24. & 19 or 20 or 21 or 22 or 23 \\
\hline 25. & Child* \\
\hline 26. & Newborn \\
\hline 27. & Infant \\
\hline 28. & Baby \\
\hline 29. & Early years \\
\hline 30. & Toddler \\
\hline 31. & Parent* \\
\hline 32. & Guardian \\
\hline 33. & 25 or 26 or 27 or 28 or 29 or 30 or 31 or 32 \\
\hline 34. & 12 and 18 and 24 and 33 \\
\hline & \\
\hline & \\
\hline & \\
\hline
\end{tabular}

Databases searched:

- Embase: 1974 to 2020 week 37

- Ovid MELINE ® and Epub Ahead of Print, In-Process \& Other Non-Indexed citations and daily: 1946 to September 16, 2020

- Global Health: 1973 to 2020 Week 37

- APA PsycInfo: 1806 to September week 12020 
- Scopus: 1788 to September 172020

- Web of Science core collection: data last updated 2020-08-19

○ Science Citation Index Expanded (SCI-EXPANDED) --1900-present

○ Social Sciences Citation Index (SSCI) --1956-present

○ Arts \& Humanities Citation Index (A\&HCI) --1975-present

○ Conference Proceedings Citation Index- Science (CPCI-S) --1990-present

○ Conference Proceedings Citation Index- Social Science \& Humanities (CPCISSH) --1990-present

○ Emerging Sources Citation Index (ESCI) --2015-present 


\section{Supplementary materials. Full table of methods and results of studies included in systematic review}

\begin{tabular}{|c|c|c|c|c|c|}
\hline Reference & $\begin{array}{l}\text { Study design, location } \\
\text { (dates of data } \\
\text { collection) }\end{array}$ & $\begin{array}{l}\text { Number of participants } \\
\text { (age) }\end{array}$ & Inclusion criteria & $\begin{array}{l}\text { Attitudes towards vaccine mandates / mandatory } \\
\text { vaccination }\end{array}$ & $\begin{array}{l}\text { Risk } \\
\text { of } \\
\text { bias }\end{array}$ \\
\hline $\begin{array}{l}\text { Adams et al } 2015 \\
\text { [17]; Adams et al } \\
2016 \text { [23]; Flynn et } \\
\text { al } 2017 \text { [31]; } \\
\text { McNaughton et al } \\
2016 \text { [26] }\end{array}$ & $\begin{array}{l}\text { In-person focus groups } \\
\text { (autumn and winter of } \\
\text { 2013-14) and online } \\
\text { discrete choice } \\
\text { experiment, England } \\
\text { (December 2014) }\end{array}$ & $\begin{array}{l}\text { Focus groups: } 91 \text { (not } \\
\text { reported) }\end{array}$ & $\begin{array}{l}\text { Focus groups: parents and carers } \\
\text { of preschool children resident in } \\
\text { the North-East of England } \\
\text { (including a group from a } \\
\text { geographical subarea that had } \\
\text { experienced a measles outbreak } \\
\text { in 2012-13) }\end{array}$ & $\begin{array}{l}\text { Focus groups: Financial incentives were } \\
\text { thought of as inappropriate, displayed dismay } \\
\text { that this type of incentive scheme would be } \\
\text { under consideration. Universal incentives } \\
\text { (offered to all regardless of vaccination status } \\
\text { of child or socio-economic status of parent) } \\
\text { was noted as positive, but a small financial } \\
\text { incentive may not be attractive to more } \\
\text { affluent parents. If financial reward were } \\
\text { introduced, it would need to be a nationwide } \\
\text { roll-out to ensure fairness for all parents from } \\
\text { all backgrounds. Universal reward may } \\
\text { encourage parents who do not prioritise } \\
\text { vaccinations. Incentives might be seen } \\
\text { positively in disadvantaged groups as a way of } \\
\text { supplementing income from work / benefits. } \\
\text { Concerns (from parents in more affluent } \\
\text { areas) that financial incentives would create a } \\
\text { divide between rich (who could afford not to } \\
\text { vaccinate their child) and poor (who could not } \\
\text { afford to disregard a payment). Targeting } \\
\text { financial incentives only to parents of children } \\
\text { who were not vaccinated would lead parents of } \\
\text { vaccinated children who had fulfilled their } \\
\text { 'obligations' as feeling penalised. Targeted } \\
\text { financial incentives could lead people to play } \\
\text { the system. Financial reward should not be a } \\
\text { factor when deciding to immunise one's child. } \\
\text { Financial incentives might be an inappropriate }\end{array}$ & 9 \\
\hline
\end{tabular}


use of resources when public services are being cut. Having immunisations free of charge on the NHS should be incentive enough. Would prefer to see public funds used to improve children's quality of life in a sustainable way.

Quasi-mandatory schemes were seen as preferable to financial incentives, with many advantages. Perceived as fairer and more equitable. Agreed that unimmunised children should be excluded from interacting with other children in daycare or school settings. Introduction of quasi-mandatory scheme could facilitate the normalisation of immunisation behaviour, and to encourage parents who had not prioritised immunisation. Mandating immunisation for childcare / education would provide peace of mind for parents. Child's right to socialise / be educated should be respected. Refusing the child entry to daycare/school would punish the child and jeopardise their future rather than punishing the parent. Concern about their child being unable to attend school as a consequence of their immunisation decision (as parents could be prosecuted under legislation in place at the time for taking their child out of school during term time). Concern that introduction of quasi-mandatory scheme could be interpreted as removal of parents' choice, which parents felt was their right living in a democratic society. Implementation of quasi-mandatory scheme could mean that parents with the resources to do so could opt their child out of state education and home-school or pay for private tuition/daycare. 
Discrete choice experiment. $521, \mathrm{n}=259$ in the "at high risk" group (mean age 33.8 years, $\mathrm{SD}=6.9) . \mathrm{N}=262$ in the "not at high risk group" (mean age $=34.3$ years, $\mathrm{SD}=5.1)$
Discrete choice experiment. Parents or guardians of a child 18 years or older themselves, who lived in England and who were members of ResearchNow's online panel. aged less than 5 years, who were

Discrete choice experiment. Parental preference

for: format of information received, type of

reward (cash vs none; voucher vs none),

greater value of reward, parents receiving

reward (universal reward vs targeted).

"At high risk" parents, parental preference for: format of information received, type of reward

(cash vs none; voucher vs none), value of reward, parents receiving reward (universal reward vs targeted).

"Not at high risk" parents, parental preference for: format of information received, type of reward, greater value of reward, parents receiving reward (universal reward vs

\section{targeted).}

\begin{tabular}{|c|c|c|c|c|c|}
\hline $\begin{array}{l}\text { Aharon et al } 2017 \\
\text { [32] }\end{array}$ & $\begin{array}{l}\text { Stratified case-control } \\
\text { study with a } \\
\text { retrospective cohort, } \\
\text { Israel }(* *)\end{array}$ & $\begin{array}{l}\text { Total } n=731 . n=209 \text { who } \\
\text { had not completed one of } \\
\text { more recommended } \\
\text { vaccination (mean age } \\
38.58, \text { SD } 5.35 \text { ). } n=422 \\
\text { who had completed } \\
\text { recommended vaccinations } \\
\text { (mean age } 36.17, \text { SD 5.47) }\end{array}$ & $\begin{array}{l}\text { Parents of children aged } 3 \text { to } 4 \\
\text { years recruited from infants born } \\
\text { in } 2009 \text { registered at the Mother } \\
\text { Child Health Clinics (MCHC) }\end{array}$ & $\begin{array}{l}\text { Mandatory administration of vaccinations goes } \\
\text { against freedom of choice: greater education, } \\
\text { greater critical health literacy (ability to } \\
\text { critically analyse medical information) }\end{array}$ & 7 \\
\hline $\begin{array}{l}\text { Gardner et al } 2010 \\
{[28]}\end{array}$ & $\begin{array}{l}\text { Qualitative focus } \\
\text { groups, UK (Summer } \\
\text { 2008) }\end{array}$ & 28 (mean age 33 years) & $\begin{array}{l}\text { Parents of children aged } 5 \text { years } \\
\text { and under }\end{array}$ & $\begin{array}{l}\text { MMR as a requirement for school entry and } \\
\text { withholding welfare payments from parents of } \\
\text { non-vaccinated children: ethical concerns about } \\
\text { perceived disempowerment of parents through } \\
\text { removal of consent. Withholding welfare } \\
\text { payments expected to affect low-income } \\
\text { families disproportionately. Objections to } \\
\text { penalising parents who did not want to } \\
\text { vaccinate their child because of safety } \\
\text { concerns, especially those from lower-income } \\
\text { backgrounds who might feel most pressurised } \\
\text { by scheme. Schemes inappropriately } \\
\text { positioned vaccination as a means to acquire }\end{array}$ & 5 \\
\hline
\end{tabular}


financial benefits/secure a school space;

protecting the child from illness should be the sole motivation for vaccination decisions.

\begin{tabular}{|c|c|c|c|c|c|}
\hline & & & & & \\
\hline $\begin{array}{l}\text { Grossman et al } \\
2019 \text { [33] }\end{array}$ & $\begin{array}{l}\text { Telephone interview, } \\
\text { Israel (October 2008, } \\
\text { October 2016) }\end{array}$ & $\begin{array}{l}\text { October 2008: } 360 \text { (not } \\
\text { reported) } \\
\text { October 2016: } 360 \text { (not } \\
\text { reported) }\end{array}$ & $\begin{array}{l}\text { Representative sample of parents } \\
\text { of children aged } 0 \text { to } 6 \text { years }\end{array}$ & $\begin{array}{l}\text { Support for a requirement for documentation of } \\
\text { full vaccination before enrolment in kindergarten: } \\
\text { October } 2008,71 \% \text {; October } 2016,66 \% \text { [no } \\
\text { significant difference]. }\end{array}$ & 7 \\
\hline $\begin{array}{l}\text { Helps et al } 2018 \\
{[24]}\end{array}$ & $\begin{array}{l}\text { Semi-structured face- } \\
\text { to-face qualitative } \\
\text { interviews, Australia } \\
\text { (October } 2015 \text { to } \\
\text { October 2016) }\end{array}$ & 31 (not reported) & $\begin{array}{l}\text { Parents from the Northern NSW } \\
\text { coastal area of Byron Shire, } \\
\text { Australia who had decided to } \\
\text { discontinue or decline all } \\
\text { vaccinations for their children }\end{array}$ & $\begin{array}{l}\text { Disdain towards introduction of 'No Jab No } \\
\text { Pay' scheme. Families who were } \\
\text { currently/expected to be impacted by scheme } \\
\text { were attempting to minimise impact on their } \\
\text { finances and re-evaluating how to manage } \\
\text { without the support (e.g. increasing extended } \\
\text { family support, reducing work and study } \\
\text { commitments, informal child care } \\
\text { arrangements, house sharing or relocating). } \\
\text { Parents questioned the integrity of the policy, } \\
\text { noting that it was instigated and named by a } \\
\text { media organisation, and then developed by } \\
\text { politicians. Perceived financial incentives for } \\
\text { vaccination as coercive; upset that health } \\
\text { professionals helped to implement informed } \\
\text { consent guidelines. Parents noted that there is } \\
\text { no fault vaccine injury compensation scheme. } \\
\text { Belief that education should be highest } \\
\text { priority for all children, and that no child } \\
\text { should be denied it by linking childcare } \\
\text { affordability or access to public health } \\
\text { initiatives. Belief that no government measure } \\
\text { would change parents' minds about } \\
\text { vaccinating their children. If further sanctions } \\
\text { were imposed, parents would consider } \\
\text { homeschooling/use unregistered childcare } \\
\text { providers/moving overseas, as well as get } \\
\text { involved in protest action including falsifying } \\
\text { vaccine documentation. Commitment to }\end{array}$ & 10 \\
\hline
\end{tabular}




\begin{tabular}{|c|c|c|c|c|c|}
\hline & & & & themselves/their children. & \\
\hline $\begin{array}{l}\text { Kalucka \& Lopata } \\
2016[41]\end{array}$ & $\begin{array}{l}\text { Survey, Poland (not } \\
\text { reported) }\end{array}$ & $\begin{array}{l}\text { 140. Group } 1, \mathrm{n}=78 \text { with } \\
\text { one child aged } 6 \text { years or } \\
\text { under (mean age } 29.3 \text { years } \\
\pm 3.0 \text { ). Group } 2: \mathrm{n}=62 \text { with } \\
\text { one or two children aged } 18 \\
\text { to } 19 \text { years (mean age } 47.6 \\
\text { years } \pm 5 \text { ) }\end{array}$ & $\begin{array}{l}\text { Parents with children; survey } \\
\text { completed during a medical visit }\end{array}$ & $\begin{array}{l}\text { Believe mandatory vaccination is needed: group } \\
1,70.5 \% \text {; group } 2,93.5 \% \text { [statistically significant } \\
\text { difference]. } \\
\text { Believe there are too many vaccines in the } \\
\text { mandatory immunization schedule: group } 1 \text {, } \\
64.1 \% \text {; group } 2,32.3 \% \text { [statistically significant } \\
\text { difference]. }\end{array}$ & 3 \\
\hline $\begin{array}{l}\text { Kennedy et al } 2005 \\
{[30]}\end{array}$ & $\begin{array}{l}\text { Postal survey, USA } \\
\text { (May to August 2002) }\end{array}$ & $\begin{array}{l}1527 \text { (aged } 18 \text { to } 29 \text { years, } \\
n=181 ; \text { aged } 30 \text { to } 39 \text { years, } \\
n=524 ; \text { aged } 40-49 \text { years, } \\
n=625 ; \text { aged } 50+\text { years, } \\
n=197)\end{array}$ & $\begin{array}{l}\text { Parents with children aged } 18 \\
\text { years or under living in the } \\
\text { household }\end{array}$ & $\begin{array}{l}\text { Believed that children should be allowed to go to } \\
\text { public school even if not vaccinated: } 12 \% \\
\text { Factors associated with opposing compulsory } \\
\text { vaccination (univariate): gender, white ethnicity, } \\
\text { age, lower household income, education, larger } \\
\text { household size, philosophical exemption } \\
\text { available in state. }\end{array}$ & 9 \\
\hline $\begin{array}{l}\text { Kennedy \& Gust } \\
2005[34]\end{array}$ & $\begin{array}{l}\text { Postal survey, USA } \\
\text { (May to August 2003) }\end{array}$ & $\begin{array}{l}936 \text { (aged } 18 \text { to } 29 \text { years, } \\
n=64 ; \text { aged } 30 \text { to } 44 \text { years, } \\
n=553 ; \text { aged } 45 \text { years and } \\
\text { over, } n=319)\end{array}$ & $\begin{array}{l}\text { Parents or guardians of at least } \\
\text { one child aged } 18 \text { years or under, } \\
\text { and who answered the question } \\
\text { about the type of school their } \\
\text { youngest child attended }\end{array}$ & $\begin{array}{l}\text { Believed that states should grant immunisation } \\
\text { exemptions for religious beliefs: } 22 \% \text { yes, } 55 \% \\
\text { no, } 23 \% \text { don't know. Parents of home-schooled } \\
\text { children more likely to endorse this belief than } \\
\text { parents of children in public and private school. } \\
\text { Believed that states should grant immunisation } \\
\text { exemptions for personal beliefs: } 17 \% \text { yes, } 62 \% \\
\text { no, } 22 \% \text { don't know. Parents of home-schooled } \\
\text { children more likely to endorse this belief than } \\
\text { parents of children in public and private school. }\end{array}$ & 7 \\
\hline $\begin{array}{l}\text { Krasnicka et al } \\
2018 \text { [36]; } \\
\text { Krasnicka et al } \\
2020[37]\end{array}$ & $\begin{array}{l}\text { Cross-sectional } \\
\text { survey, Poland (July } \\
2015 \text { to June 2016) }\end{array}$ & $\begin{array}{l}300(30 \% \text { aged } 18 \text { to } 30 \\
\text { years, } 46.3 \% \text { aged } 31 \text { to } 40 \\
\text { years, } 23.7 \% \text { aged } 41 \text { to } 50 \\
\text { years })\end{array}$ & $\begin{array}{l}\text { Parents attending with } \\
\text { children to the visits to the } \\
\text { ProMedica Family Medicine } \\
\text { Centre" in Bialystok. }\end{array}$ & $\begin{array}{l}\text { Belief that vaccines should be mandatory: sex, } \\
\text { older age, parental education, better financial } \\
\text { situation, had vaccinated their child, child had } \\
\text { experienced an adverse effect from vaccination. }\end{array}$ & 5 \\
\hline $\begin{array}{l}\text { Krok-Schoen et al } \\
2018 \text { [35] }\end{array}$ & $\begin{array}{l}\text { Telephone survey, } \\
\text { USA (February } 2013\end{array}$ & $\begin{array}{l}337 \text { (mean age } 43.5 \text { years, } \\
\mathrm{SD}=6.7 \text { ) }\end{array}$ & $\begin{array}{l}\text { Rural Ohio Appalachian parents } \\
\text { aged } 18 \text { years or over; able to }\end{array}$ & $\begin{array}{l}\text { Belief that parents should have the right to refuse } \\
\text { vaccines that are required for schools for any }\end{array}$ & 7 \\
\hline
\end{tabular}

autonomy in health decisions had become

stronger since introduction of No Jab No Pay

legislation, and were worried about a

"slippery slope" towards lower personal

choice in medical decisions for

themselves/their children.

Believe mandatory vaccination is needed: group

$1,70.5 \%$; group $2,93.5 \%$ [statistically significan

(6) difference].

Believed th

actors associated with opposing compulsory

household size, philosophical exemption

available in state.

no, 23\% don't know. Parents of home-schooled

children more likely to endorse this belief than

prents of children in public and private school.

xemptions for personal beliefs: $17 \%$ yes, $62 \%$

$0,22 \%$ don't know. Parents of home-schooled

Belief that vaccines should be mandatory: sex, 
and March 2014)

\begin{tabular}{ll}
\hline Lee et al 2016 [38] & $\begin{array}{l}\text { Case-control postal } \\
\text { survey, USA (not }\end{array}$
\end{tabular} reported)

277 parents of children with non-medical exemptions (not reported).

976 parents of fully

vaccinated children (not reported). speak, read and write English; who were the parent or legal guardian of a girl aged 9 to 17 years ; and who did not have a child who had received the HPV vaccine
Parents from selected private and public elementary schools in Colorado, Massachusetts, Missouri and Washington from 2002 to 2003.

\begin{tabular}{|c|c|c|c|c|c|}
\hline \multirow[b]{2}{*}{$\begin{array}{l}\text { Makaric et al } 2018 \\
\text { [39] }\end{array}$} & \multirow[b]{2}{*}{$\begin{array}{l}\text { Cross-sectional } \\
\text { survey, Croatia (1 } \\
\text { May to } 1 \text { June 2017) }\end{array}$} & \multirow[b]{2}{*}{$\begin{array}{l}542 \text { (mean age } 38.1 \text { years, } \\
\mathrm{SD}=6.3 \text { ) }\end{array}$} & \multirow[b]{2}{*}{$\begin{array}{l}\text { Parents of children aged } 6 \text { years } \\
\text { that attended School Health } \\
\text { Services in Zagreb. }\end{array}$} & \multicolumn{2}{|l|}{ healthcare providers. } \\
\hline & & & & $\begin{array}{l}\text { Childhood vaccines should remain mandatory: } \\
72.6 \% \text { agree, } 12.8 \% \text { disagree, } 14.5 \% \text { undecided. }\end{array}$ & 3 \\
\hline $\begin{array}{l}\text { McDonald et al et } \\
\text { al } 2019 \text { [25] }\end{array}$ & $\begin{array}{l}\text { Face-to-face/telephone } \\
\text { qualitative interviews, } \\
\text { USA (August to } \\
\text { September 2017) }\end{array}$ & $\begin{array}{l}19(26 \text { to } 30 \text { years, } n=11 ; 31 \\
\text { to } 35 \text { years, } n=2 ; 36 \text { to } 40 \\
\text { years, } n=9 ; 41+\text { years, } n=2)\end{array}$ & $\begin{array}{l}\text { Parents with at least one child in } \\
\text { transitional kindergarten to } 12 \text { th } \\
\text { grade for the } 2016-2017 \text { or } 2017- \\
2018 \text { school year using any of the } \\
\text { four forms of legalized home- } \\
\text { based education recognized by } \\
\text { the state of California. }\end{array}$ & $\begin{array}{l}\text { Believe elimination of personal belief } \\
\text { exemption is an infringement on parental } \\
\text { autonomy. }\end{array}$ & 10 \\
\hline $\begin{array}{l}\text { Tarrant \& } \\
\text { Thompson } 2008 \\
{[27]}\end{array}$ & $\begin{array}{l}\text { Qualitative interviews, } \\
\text { Hong Kong (not } \\
\text { reported) }\end{array}$ & $\begin{array}{l}15 \text { ("majority of } \\
\text { participants }(93.3 \%) \text { were } \\
\text { between } 26 \text { and } 40 \text { years of } \\
\text { age") }\end{array}$ & $\begin{array}{l}\text { Hong Kong parents of children } \\
\text { aged } 6 \text { months to } 3 \text { years, who } \\
\text { had no major congenital } \\
\text { anomalies and who were enrolled }\end{array}$ & $\begin{array}{l}\text { Children cannot attend school if they are fully } \\
\text { immunised and schooling is very important; } \\
\text { this is a driver for vaccination. Full } \\
\text { vaccination is important to ensure that }\end{array}$ & 10 \\
\hline
\end{tabular}

reason: $47 \%$ agree.

Associations with belief that parents should have the right to refuse vaccines that are required for schools for any reason: age, sex, education, marital status, annual household income, parttime employment / disabled / unemployed / retired (vs full-time employment), current health insurance, general health score, smoking status, religious family, religiosity, religious attendance, place of worship's opinion on vaccines, Republican and Independent political affiliation (vs Democrat)

Belief that parents should be allowed to send unvaccinated children to school: distrust of the government, distrust of healthcare providers. Belief that immunisation requirement laws interfere with parents making informed decisions about vaccines: distrust of the government, distrust of healthcare providers.

Oppose laws authorising an immunisation registry: distrust of the government, distrust of healthcare providers.

Childhood vaccines should remain mandatory:

\section{Believe elimination of personal belie} to 35 years, $n=2 ; 36$ to 40 focognized by

Thompson 2008 Hong Kong (not between 26 and 40 years of had no major congenital

\section{immunised and schooling is very important}

vaccination is important to ensure that 
in a larger study of parents who had attended a major paediatric referral clinic at a university

teaching hospital in Hong Kong.

\begin{tabular}{|c|c|c|c|}
\hline $\begin{array}{l}\text { Trent et al } 2019 \\
\text { [29] }\end{array}$ & $\begin{array}{l}\text { Online cross-sectional } \\
\text { survey, Australia } \\
\text { (May 2017) }\end{array}$ & $\begin{array}{l}411 \text { (mean age } 33.9 \text { years, } \\
\text { inter-quartile range } 29 \text { to } \\
\text { 39) }\end{array}$ & $\begin{array}{l}\text { Parents of children aged less than } \\
\text { five years, who were aged } 18 \text { to } \\
60 \text { years themselves. }\end{array}$ \\
\hline
\end{tabular}

[40]

Online cross-sectional survey, USA (April to

August 2016)

\section{7 (“55}

of the participants were in

the 31-40- and 41-

50 -year-old age range") children do not spread illness to other children in school.

\section{Support for the No Jab No Pay policy: $82 \%$}

60 years themselves.

$(n=337)$ yes.

Associated with being in favour of the No Jab No Pay policy (univariate): age, female sex, born in Australia, ethnicity, education, state, child attends child care centre or family daycare, needs

financial benefits to afford family expenses,

perceived risk of measles as high/very high to

unvaccinated child, not previously registered a conscientious objection.

Associated with being in favour of the No Jab No Pay policy (multivariate): age, sex, born in

Australia, ethnicity, education, state, child attends child care centre or family daycare, needs

financial benefits to afford family expenses,

perceived risk of measles as high/very high to

unvaccinated child, not previously registered a

conscientious objection.

Opinions regarding the government's role in

Parents of children who were

homeschooled and who attended

public/private schools in

Washington State.

vaccination (Items: individual states should gran

vaccine exemptions for religious

beliefs / individual states should grant vaccine exemptions for personal beliefs / it is the

government's right to mandate vaccinations / it is the government's responsibility to mandate vaccinations) - average score $=2.581 / 6$.

Associations with believing that individual states should grant vaccine exemptions for religious

beliefs: homeschooling parents (vs

public/private school parents)

Associations with believing that individual states should grant vaccine exemptions for personal 
beliefs: homeschooling parents (vs

public/private school parents)

Associations with believing that it is the

government's right to mandate vaccinations:

public/private school parents (vs

homeschooling parents)

Associations with believing that it is the

government's responsibility to mandate

vaccinations: homeschooling parents (vs public/private school parents) 
medRxiv preprint doi: https://doi.org/10.1101/2021.02.24.21250288; this version posted February 26, 2021. The copyright holder for this preprint (which was not certified by peer review) is the author/funder, who has granted medRxiv a license to display the preprint in perpetuity.

It is made available under a CC-BY 4.0 International license . 